\title{
IMPACT OF SENSITIZATION ABOUT HAND WASHING ON SECOND MBBS MEDICAL STUDENTS
}

\author{
K. V. Ingole1, Durgesh Deshmukh², Sonika Watmore ${ }^{3}$ \\ ${ }_{1}^{1}$ Professor \& HOD, Department of Microbiology, Dr. V. M. Government Medical College, Solapur. \\ ${ }^{2}$ Assistant Professor, Shri Vasantrao Naik Government Medical College, Yavatmal. \\ ${ }_{3}^{3}{ }^{\text {rd }}$ Year Post Graduate Student, Shri Vasantrao Naik Government Medical College, Yavatmal.
}

\section{ABSTRACT}

\section{BACKGROUND}

In modern day medical practice hospital acquired infection is a very significant problem, increasing the morbidity, mortality, length of hospital stay and economic burden on hospitals. Hence its teaching in curriculum of UG student is important.

\section{METHODS}

In this study we have involved 100, medical students of second year MBBS course. All the students were divided into two groups, group A and group B. Both these groups were exposed to pre-test and the culture of hand swabs was done. Then group A was sensitized about hand hygiene. Post-test was performed on both the groups and again culture of hand swab was done and the results of post-test of both groups were compared.

\section{RESULTS}

In our study when pre-test was performed significantly less knowledge was documented in UG students of both the groups. In our study Staphylococcus aureus was the predominant bacterial isolate observed from the culture of the hand swabs in both groups. After sensitization there was significant increase $(\mathrm{P}<0.05)$ in knowledge and also there was a significant decrease $(\mathrm{P}<0.05)$ in bacterial culture in hands of sensitized group $\mathrm{A}$.

\section{CONCLUSION}

Sensitization and teaching of hand hygiene and preventive strategy for hospital acquired infection in UG students is important.

\section{KEYWORDS}

Medical Student; Hand Hygiene; Hospital Acquired Infection.

HOW TO CITE THIS ARTICLE: Ingole KV, Deshmukh D, Watmore S. Impact of sensitization about hand washing on second MBBS medical students. J Evolution Med Dent Sci 2016;5(3):185-188, DOI: 10.14260/jemds/2016/42

\section{INTRODUCTION}

In modern day medical practice hospital acquired infection is a very significant problem, increasing the morbidity, mortality, length of hospital stay and economic burden on hospital. ${ }^{1}$ The risk of developing and transmission of these infections in patients are increased by repeated and prolonged episodes of hospitalization, irrational drug prescription and presence of indwelling medical devices.

Methicillin-Resistant Staphylococcus Aureus (MRSA) is one of the most important causes of hospital acquired infections. ${ }^{2}$ MRSA infection causes sequelae such as sepsis, abscesses, wound infection, skin and soft tissue infection, and bloodstream infection. However, it can also colonize healthy humans without causing infection.

Approximately, $25 \%$ to $30 \%$ of all people are colonized in the nose with Staphylococcus aureus. ${ }^{3}$ less than $2 \%{ }^{4}$ are colonized with MRSA. About 5\% health care carriers develop clinical disease.$^{5}$ and transmission of MRSA from health care workers to family members is not uncommon. ${ }^{6}$

Financial or Other, Competing Interest: None.

Submission 03-12-2015, Peer Review 04-12-2015,

Acceptance 06-01-2016, Published 08-01-2016.

Corresponding Author:

Dr. K. V. Ingole,

Department of Microbiology,

Dr. V. M. Government Medical College,

Solapur.

E-mail: profesorkvi4@gmail.com

DOI:10.14260/jemds/2016/42
Thus health care workers act as disseminators of infection in the hospital environment. MRSA is primarily transferred from one patient to another via the hands of health care workers. ${ }^{5}$ Thus one of the main interventions to halt transmission of MRSA can be by preventive strategies directed at health care workers, in the form of compliance with basic infection prevention and control strategies, which include hand hygiene and contact precautions.

While there is a continuing discussion whether health care workers should also be screened on a regular basis in endemic, non-outbreak situations. ${ }^{7}$ our rationale behind active screening of health care workers was to set up baseline data for possible future epidemics and guide formulations of an infection control strategy in a hospital that lacked any structured infection control plan.

We consider screening of health workers to be of prime importance because: 1) Health workers provide the main transmission mode among patients, the spread of MRSA in the hospital largely depends on prevalence among health workers. 2) Colonized health workers have been known to cause outbreaks in various setting in the past. ${ }^{8}$ 3)Unlike patients health care workers are always present in the hospital, thus they can be included in the long term, continuous infection control strategy.

Awareness of carrier status has been known to improve health workers compliance to preventive strategies at the hospital and at their homes. ${ }^{6}$ 4) MRSA is an occupational hazard to the health worker in the form of life-threatening 
infections and frequent transmission to family members. ${ }^{8}$ detection of colonized status will enable the health worker to begin topical decolonization and prevent spread to colleagues at work and to family members at home.

The present study was conducted to find the importance of hand washing in infection prevention and its inclusion in the curriculum of microbiology and also to evaluate over all awareness about hand washing in second MBBS medical students.

\section{MATERIAL AND METHODS \\ Study Population}

This institution based interventional prospective study was carried out in department of Microbiology and clinical department of Shri Vasantrao Naik Government Medical College, Yavatmal, which has included 100 second MBBS students among those who were posted for more than one month in clinical posting and hospital premises from the same college with systematic randomization. These students were then divided into two groups

Group 1 (Study group): 50 second MBBS student batch A. Group B (Control group): 50 second MBBS student batch B.

Consent was obtained from all the participants. After randomization pre-test (Annexure I) was given to both the groups. The swabs from the web spaces of hands were collected when they come out of hospital ward and microbiology practical classes.

Then intervention by sensitization was done in the form of demonstration and short lecture on hand washing in the study group. On the next day post-test (Annexure I) of both groups i.e. control and study group along with second swab was obtained. Sensitization was done after post-test.

Data analysis was done by mean, standard deviation and P-value was calculated using SPSS software.

\section{OBSERVATION AND RESULT}

\begin{tabular}{|c|c|}
\hline Group & Mean Score in pretest \\
\hline A & 4.33 \\
\hline B & 4.66 \\
\hline \multicolumn{2}{|c|}{ Table 1. Assessment of knowledge about hand } \\
washes by pretest score
\end{tabular}

a) Group A

\begin{tabular}{|c|c|c|}
\hline No. & Bacterial Isolates & $\begin{array}{c}\text { Number } \\
\text { (Percentage) }\end{array}$ \\
\hline 1 & Staphylococcus aureus & $34(68 \%)$ \\
\hline 2 & Escherichia coli & $1(2 \%)$ \\
\hline 3 & Klebsiella pneumoniae & $2(8 \%)$ \\
\hline 4 & Pseudomonas aeruginosa & $1(2 \%)$ \\
\hline 5 & $\begin{array}{r}\text { No bacterial isolates } \\
\text { grown }\end{array}$ & $12(24 \%)$ \\
\hline \multicolumn{2}{|c|}{$\begin{array}{c}\text { Table 2. Bacterial isolates grown in swabs taken } \\
\text { from hands of students in different groups }\end{array}$} \\
\hline
\end{tabular}

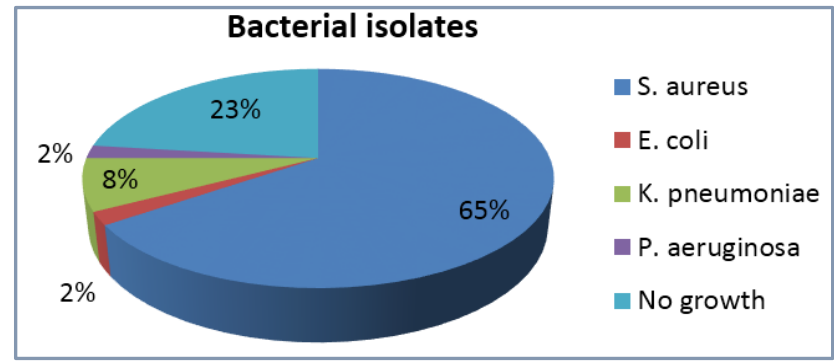

b) Group B:

\begin{tabular}{|c|c|c|}
\hline No. & Bacterial Isolates & $\begin{array}{c}\text { Number } \\
\text { (Percentage) }\end{array}$ \\
\hline 1 & Staphylococcus aureus & $40(80 \%)$ \\
\hline 2 & Escherichia coli & $2(4 \%)$ \\
\hline 3 & Klebsiella pneumoniae & 0 \\
\hline 4 & Pseudomonas aeruginosa & 0 \\
\hline 5 & $\begin{array}{c}\text { No bacterial isolates } \\
\text { grown }\end{array}$ & $8(16 \%)$ \\
\hline
\end{tabular}

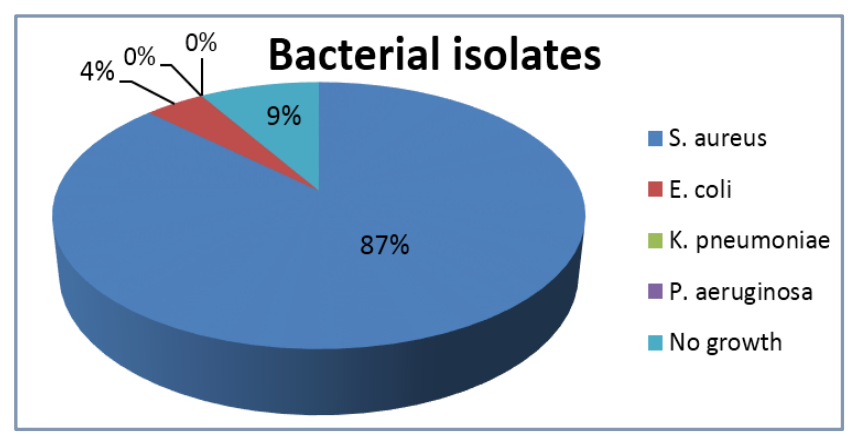

3. Assessment of knowledge about hand washing after sensitization to Group A.

\begin{tabular}{|c|c|}
\hline Group & Mean score in post-test \\
\hline A & 8.77 \\
\hline B & 4.88 \\
\hline \multicolumn{2}{|c|}{ P value $<0.005$} \\
\hline
\end{tabular}

4. a) Bacterial isolates grown in swabs from hands after sensitization to Group A.

\begin{tabular}{|c|c|c|}
\hline No. & Bacterial Isolates & $\begin{array}{c}\text { Number } \\
\text { (Percentage) }\end{array}$ \\
\hline 1 & Staphylococcus aureus & $4(8 \%)$ \\
\hline 2 & Escherichia coli & 0 \\
\hline 3 & Klebsiella pneumonia & 0 \\
\hline 4 & Pseudomonas aeruginosa & 0 \\
\hline 5 & $\begin{array}{c}\text { No bacterial isolates } \\
\text { grown }\end{array}$ & 0 \\
\hline \multicolumn{2}{|c|}{ P value <0.005 } \\
\hline
\end{tabular}

b) Bacterial isolates grown in swabs from hands after sensitization to Group B.

\begin{tabular}{|c|c|c|}
\hline No. & Bacterial Isolates & $\begin{array}{c}\text { Number } \\
\text { (Percentage) }\end{array}$ \\
\hline 1 & Staphylococcus aureus & $37(74 \%)$ \\
\hline 2 & Escherichia coli & $1(2 \%)$ \\
\hline 3 & Klebsiella pneumonia & 0 \\
\hline 4 & Pseudomonas aeruginosa & 0 \\
\hline 5 & $\begin{array}{c}\text { No bacterial isolates } \\
\text { grown }\end{array}$ & $12(24 \%)$ \\
\hline \multicolumn{2}{|c|}{ P value $>0.005$} \\
\hline
\end{tabular}


ANNEXURE - I

\section{(PRETEST/POST TEST)}

\section{Hand Hygiene Knowledge Questionnaire for Medical student.}

1 ROLL NO:............................ 2 Date:
3. Gender: Male/Female 4 Age:

\section{Tick Only One Answer to Each Question}

1. Did you receive formal training in hand hygiene in the last three years? Yes No.

2. Which of the following is the main route of crosstransmission of potentially harmful germs between patients in a health-care facility? (Tick one answer only).

a. Health-care workers' hands when not clean

b. Air circulating in the hospital

c. Patients' exposure to colonised surfaces (i.e., beds, chairs, tables, floors)

d. Sharing non-invasive objects (i.e., stethoscopes, pressure cuffs, etc.) between patients.

3. What is the most frequent source of germs responsible for health care-associated infections? (Tick one answer only)

a. The hospital's water system

b. The hospital air

c. Germs already present on or within the patient

d. The hospital environment (Surfaces).

4. Which of the following hand hygiene actions prevents transmission of germs to the patient?

a. Before touching a patient Yes No

b. Immediately after a risk of body fluid exposure Yes No

c. After exposure to the immediate surroundings of a patient Yes No

d. Immediately before a clean/aseptic procedure Yes No.

5. Which of the following hand hygiene actions prevents transmission of germs to the health-care worker?

a. After touching a patient Yes No

b. Immediately after a risk of body fluid exposure Yes No

c. Immediately before a clean/aseptic procedure Yes No

d. After exposure to the immediate surroundings of a patient Yes No.

6. Hand wash with rubbing and using commercially available disinfectants is always better than washing the hand with soap and water - Yes /No

7. Which of the following statements on alcohol-based handrub and handwashing with soap and water are true?

a. Handrubbing causes skin dryness more than handwashing True False

b. Handrubbing is more effective against germs than handwashing True False

c. Handwashing and handrubbing are recommended to be performed in sequence True False.
8. What is the minimal time needed for alcohol-based handrub to kill most germs on your hands? (Tick one answer only).
a. 20 seconds
b. 3 seconds
c. 1 minute
d. 10 seconds.

9. How many steps are there during hand washing for hand hygiene?
a. 2 steps
b. 3 steps
c. 5 steps
d. 7 steps.

10. Which of the following should be avoided, as associated with increased likelihood of colonisation of hands with harmful germs?
a. Wearing jewellery Yes No
b. Damaged skin Yes No
c. Artificial fingernails Yes No
d. Regular use of a hand cream Yes No.

\section{DISCUSSION}

Hospital acquired infection is one of important causes of death in hospitalized patients. Preventive strategy like hand washing is very important way to decrease mortality and morbidity. Its sensitization in UG student is important strategy so that its importance can be training to UG student before they actually involve in patient management. In the present study when pretest was performed significantly less knowledge was documented in the UG student in both groups. In our study Staphylococcus aureus was predominant bacteria which was isolated in hand swabs of both groups. After sensitization there was significant increase $(\mathrm{P}<0.05)$ in knowledge and also there was a significant decrease $(\mathrm{P}<0.05)$ in bacterial carriage in hand of sensitized group A.

\section{CONCLUSION}

It is very important to sensitize and teach undergraduate student about hand hygiene and preventive strategy to control hospital acquired infection.

\section{REFERENCES}

1. Wassenberg MWM, de Wit GA, van Hout BA, et al. Quantifying cost-effectiveness of controlling nosocomial spread of antibiotic-resistant bacteria: the case of MRSA. PLoS One 2010, 5:e11562.

2. Law MR, Gill On. Hospital-acquired infection with methicillin-resistant and methicillin-sensitive staphylococci. Epidemiol Infect 1988;101:623-629.

3. Kluytmans J, van Belkum A, Verbrugh H: Nasal carriage of Staphylococcus aureus: epidemiology, underlying mechanisms and associated risk. Clin Microbiol Rev 1997; 10:505-520.

4. http://www.cdc.gov/mrsa/definition/index.html

5. Albrich WC, Harbarth S. Health-care workers: source, vector, or victim of MRSA? Lancet Infect Dis 2008;8:289-301. 
6. Eveillard M, Martin Y, Hindri N, et al. Carriage of Methicillin-Resistant Staphylococcus aureus among Hospital employees: Prevalence, Duration and Transmission to Households infection control and Hospital Epidemiology 2004;25:114-120.

7. Collins CJ. Screening of healthcare workers for methicillin-resistant Staphylococcus aureus: the debate continues for high risk non-endemic settings. J Hosp Infect 2012;80:92e93.
8. Vonberg RP, Stamm-Balderjahn S, Hansen S. How often do asymptomatic healthcare workers cause methicillinresistant Staphylococcus aureus outbreaks? A systematic evaluation. Infect Control Hosp Epidemiol 2006;27:1123-27. 